\title{
Use of reverse-transcriptase-based HIV-1 viral load assessment to confirm low viral loads in newly diagnosed patients in Switzerland
}

\author{
Beatrice N Vetter ${ }^{*}$, Cyril Shah, Jon B Huder, Jürg Böni and Jörg Schüpbach
}

\begin{abstract}
Background: Treatment-naïve patients newly diagnosed with HIV occasionally present with low viral RNA of $\leq 1^{\prime} 000$ copies/ml, raising concerns about viral load underestimation. Because falsely low or undetectable viral loads might lead to inadvertent virus transmission or treatment delays, confirmation of such cases by a sequence-independent viral load test is recommended in Switzerland.
\end{abstract}

Methods: HIV-1 RNA $\leq 1 ' 000 \mathrm{cp} / \mathrm{ml}$ by Roche's or Abbott's tests in patients newly diagnosed from 2010 to 2012 in Switzerland were subjected to viral load testing by the product-enhanced-reverse transcriptase (PERT) assay. These investigations were complemented with repeat and/or alternative viral RNA measurements.

Results: HIV-1 RNA $\leq 1 ' 000 \mathrm{cp} / \mathrm{ml}$ was observed in 71 of 1814 newly diagnosed patients. The PERT assay suggested clinically relevant viral load underestimation in 7 of 32 cases that could be investigated. In four patients, the PERT viral load was 10-1'000-fold higher; this was confirmed by alternative HIV-1 RNA tests. Six of the 7 underestimates had been obtained with meanwhile outdated versions of Roche's HIV-1 RNA test. In the seventh patient, follow-up revealed similar results for RNA and PERT based viral loads.

Conclusion: PERT assay revealed occasional severe viral load underestimation by versions of HIV-1 RNA tests meanwhile outdated. Underestimation by contemporary tests appears rare, however.

Keywords: HIV-1, Viral load underestimation, Nucleic acid test, Reverse transcriptase test, PERT assay

\section{Background}

The quantification of HIV-1 RNA in plasma has become the standard for assessing a patient's plasma viral load $(\mathrm{VL})$ at the time of diagnosis and throughout the course of the disease. Real-time PCR-based nucleic acid tests (NAT) have a high sensitivity and broad dynamic range [1] and the use of fine-tuned primer/probe sets has made it possible to detect isolates of HIV-1 groups $M$, $\mathrm{N}$, and $\mathrm{O}$ as well as all known subtypes and circulating recombinant forms. However, due to the highly variable nature of HIV, primer/probe binding to the target region occasionally can be sub-optimal, resulting in underestimation of VL $[2,3]$. It is important to establish such underestimation at the time of diagnosis, as VL monitoring will be used for monitoring disease progression and

\footnotetext{
* Correspondence: vetter.beatrice@virology.uzh.ch

Swiss National Center for Retroviruses, Institute of Medical Virology, University of Zurich, Zurich, Switzerland
}

the success of antiretroviral therapy (ART). Falsely low or even undetectable viral load due to underestimation may impact the interpretation of the success of ART and increase the risk of inadvertent virus transmission. In Switzerland, regulations on HIV confirmation testing issued by the Swiss Federal Office of Public Health (SFOPH) in 2006 therefore request that a VL $\leq 1^{\prime} 000 \mathrm{cp} / \mathrm{ml}$ be confirmed by the product-enhanced reverse transcriptase (PERT) assay, a sequence-independent test that quantifies retrovirus particles based on their content of enzymatically active reverse transcriptase (RT) [4]. This test has been available in our country since 1994, and its sensitivity is comparable to NAT $[5,6]$. VL based on the PERT assay, or on other RT-based tests, have been shown to correlate well with RNA-based VL over a wide dynamic range $\left(10^{2}-10^{6} \mathrm{cp} / \mathrm{ml}\right)[6-8]$.

Here, we analyzed the frequency of NAT-based $\mathrm{VL} \leq 1$ '000 $\mathrm{cp} / \mathrm{ml}$ among newly diagnosed, untreated 
HIV-1 patients in Switzerland and investigated whether such low VL were true or due to underestimation. To this end, we compared viral loads derived from NAT and PERT at the time of diagnosis and complemented these data with repeat and/or alternative NAT measurements. Alternative NAT involved testing in a different primer/probe target region, addressing the possibility of sequence polymorphism-associated failure of viral RNA detection.

\section{Methods}

\section{Study population and organisation}

The study included all patients newly diagnosed with HIV-1 infection as notified to the SFOPH during 01/ 2010-12/2012. NAT VL tests were performed at the time of HIV diagnosis in one of 11 Swiss HIV notification laboratories commissioned by the SFOPH, or at the Swiss National Center for Retroviruses (SNCR), commissioned by the SFOPH to serve as the national HIV reference laboratory. All laboratories are accredited by the governmental Swiss Accreditation Service (SAS) (http://www. seco.admin.ch/sas/index.html?lang=en).

PERT assays in patients that had exhibited $\leq 1 ' 000 \mathrm{cp} / \mathrm{ml}$ of HIV-1 RNA were performed at the SNCR upon request by a patient's treating physician. In most instances, a new blood sample was used for testing. If NAT and PERT VL were determined in two separate samples, collection dates for these samples had to be $\leq 100$ days apart to minimize a potential decrease in VL due to initiation of ART. All repeat and alternative NAT measurements were performed on the second sample stored at the SNCR. Plasma samples were stored at $-80^{\circ} \mathrm{C}$ and thawed once for alternative NAT and a second time for repeat NAT assessment. Measurements were performed on undiluted samples or at a maximal dilution of 1:4 in PBS.

\section{RNA viral load tests}

Laboratories performing the initial, diagnostic NAT employed one of the following CE-marked tests: Roche COBAS AmpliPrep/COBAS TaqMan HIV-1 test v1.0 (CTM1.0), Roche COBAS AmpliPrep/COBAS TaqMan HIV-1 test v2.0 (CTM2.0), Roche COBAS Amplicor HIV-1 Monitor v1.5 (CAM1.5) or Abbott RealTime HIV-1 m2000 (ARm2000). The SNCR used CTM2.0 and ARm2000 for repeat or alternative NAT. Repeat testing with CTM1.0 and CAM1.5 was not possible, as these tests were no longer available. If possible, these samples were tested with both alternative NAT platforms (CTM2.0 and ARm2000).

\section{Product-enhanced-reverse-transcriptase assay}

The PERT assay is an SAS-accredited method and was performed as described previously [7]. cDNA amplification and quantification was performed on the ABI7900
Sequence Detector (Perkin Elmer Biosystems, Norwalk, CT, U.S.A.). Median cycle threshold (Ct)-values were converted into RNA $\mathrm{cp} / \mathrm{ml}$ based on a conversion curve generated from plasma samples of 30 untreated, HIV-1 infected patients (Figure 1). NAT VL was assessed on CTM2.0 during routine testing. The PERT assay and confirmatory NAT testing on the ARm2000 platform were performed on archived samples. The lower limit of quantification for the PERT assay was at a Ct-value of 30, which corresponds to an HIV-1 RNA concentration of $78 \mathrm{cp} / \mathrm{ml}$.

\section{Duration of infection and HIV-1 subtypes}

The estimated duration of HIV infection was determined by the patient's antibody pattern in a confirmatory line immunoassay (Inno-Lia ${ }^{\text {тм }}$ HIV I/II Score) $[9,10]$. Classification into "recent" or "older" refers to an estimated duration of infection of less or more than 120 days.

HIV-1 subtype information was obtained from the Swiss drug resistance database.

\section{Ethics}

All data in this study were derived from diagnostic data contained in anonymised mandatory HIV notifications to the SFOPH. No informed consent was required for the anonymised notifications.

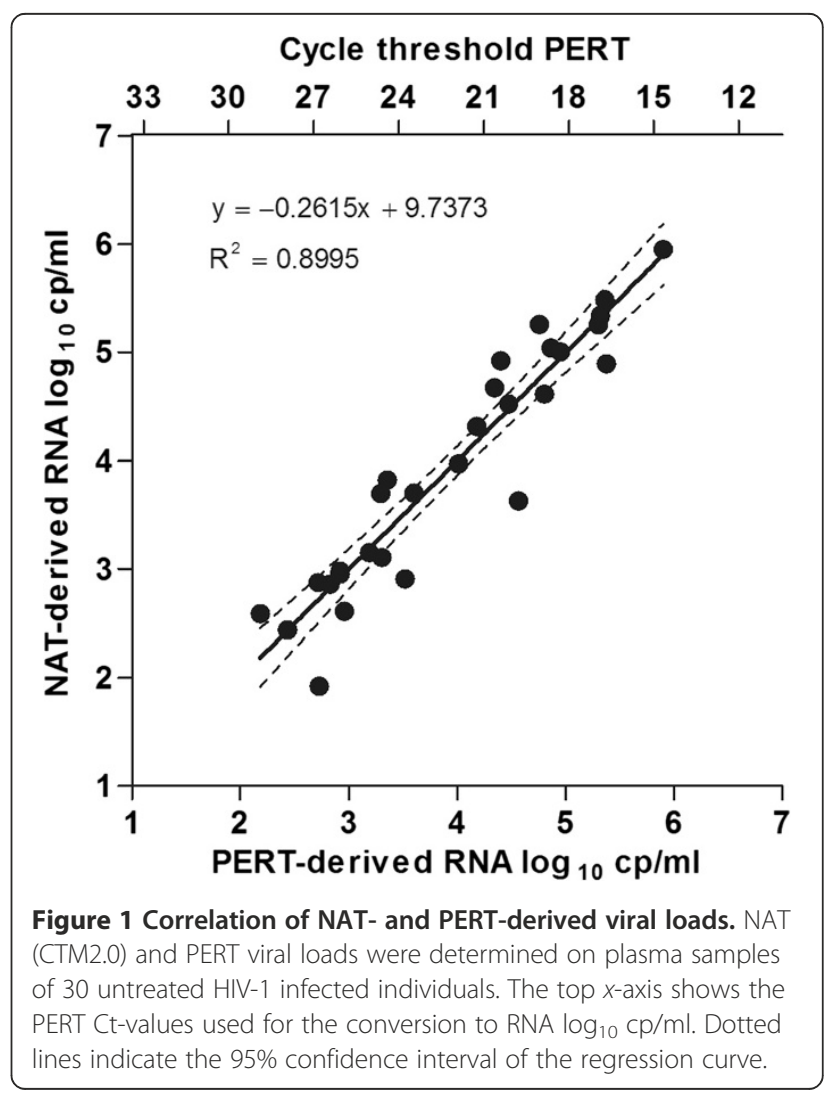




\section{Results}

Frequency and magnitude of low viral loads

During 01/2010-12/2012, the SFOPH registered 1814 patients newly diagnosed with HIV; approximately $0.5 \%$ of these were infected by HIV-2 [11]. Seventy-one (3.9\%) of the HIV-1 infected patients had an initial, diagnostic
NAT VL $\leq 1 ' 000 \mathrm{cp} / \mathrm{ml}$ in the absence of ART. Twelve of these $(0.7 \%$ of the total) had an undetectable VL. A PERT assay was performed for 32 of the 71 patients, and the low NAT VL $\leq 1^{\prime} 000 \mathrm{cp} / \mathrm{ml}$ was confirmed in 23 patients $(72 \%$ of the 32$)$ (Table 1 and Figure $2 \mathrm{~A}$ ). The remaining 9 patients had a PERT VL $>1^{\prime} 000 \mathrm{cp} / \mathrm{ml}$, with

Table 1 Summary of NAT and PERT viral load results

\begin{tabular}{|c|c|c|c|c|c|c|c|c|c|}
\hline \multirow{3}{*}{$\begin{array}{l}\text { Patient } \\
\text { ID }\end{array}$} & \multicolumn{4}{|c|}{ NAT $\mathrm{cp} / \mathrm{ml}$} & \multirow{3}{*}{$\begin{array}{l}\text { PERT } \mathrm{cp} / \mathrm{ml} \\
\text { Diagnosis }\end{array}$} & \multirow[t]{3}{*}{ Subtype } & \multirow[t]{3}{*}{$\Delta$ days samples } & \multirow[t]{3}{*}{ Recency } & \multirow[t]{3}{*}{ Year } \\
\hline & \multirow{2}{*}{$\begin{array}{c}\text { Diagnosis } \\
\text { CTM1.0 }\end{array}$} & \multirow{2}{*}{$\begin{array}{l}\text { Repeat } \\
\text { CTM1.0 }\end{array}$} & \multicolumn{2}{|c|}{ Alternative } & & & & & \\
\hline & & & СTM2.0 & ARm 2000 & & & & & \\
\hline 1 & TND & N/A & & & 295 & B & 7 & Older & 2010 \\
\hline 2 & 46 & N/A & $45^{\prime} 282$ & $46^{\prime} 885$ & $88^{\prime} 733$ & CRF01_AE & 10 & Older & 2010 \\
\hline 3 & 70 & N/A & & & TND & & 4 & Older & 2010 \\
\hline 4 & 257 & N/A & 7'728 & $16^{\prime} 635$ & 11'191 & B & 8 & Older & 2010 \\
\hline \multirow[t]{2}{*}{5} & 508 & N/A & $6 ' 254$ & 8'934 & $8^{\prime} 428$ & CRF02_AG & 15 & Older & 2011 \\
\hline & CTM2.0 & CTM2.0 & & ARm 2000 & & & & & \\
\hline 6 & TND & & & TND & TND & & 4 & Older & 2012 \\
\hline 7 & TND & & & & TND & & 14 & Recent & 2010 \\
\hline 8 & 22 & & & & TND & & 19 & Older & 2012 \\
\hline 9 & 38 & & & TND & TND & & 35 & Older & 2012 \\
\hline 10 & 47 & 66 & & 54 & TND & & 23 & Older & 2012 \\
\hline 11 & 53 & & & & TND & & 9 & Older & 2012 \\
\hline 12 & 110 & & & & TND & D & 56 & Older & 2011 \\
\hline 13 & 128 & & & 50 & TND & C & 24 & Older & 2012 \\
\hline 14 & 158 & & & 459 & 309 & & 22 & Older & 2010 \\
\hline 15 & 165 & & & 220 & 104 & & 10 & Older & 2010 \\
\hline 16 & 174 & & & 148 & 79 & & 20 & Recent & 2010 \\
\hline 17 & 210 & & & 258 & 195 & CRF02_AG & 69 & Older & 2012 \\
\hline 18 & 299 & & & 618 & 574 & B & 23 & Older & 2010 \\
\hline 19 & 447 & 62 & & 296 & 308 & & 24 & Older & 2011 \\
\hline 20 & 480 & 296 & & 209 & 82 & CRF01_AE & 12 & Older & 2012 \\
\hline 21 & 551 & & & & 1'584 & CRF02_AG & 20 & Older & 2012 \\
\hline 22 & 638 & & & & $5^{\prime} 303$ & B & 0 & Older & 2011 \\
\hline 23 & 936 & & & $2^{\prime} 761$ & 1'565 & & 0 & Older & 2010 \\
\hline \multirow[t]{2}{*}{24} & 990 & & & & 157 & CRF02_AG & 21 & Older & 2012 \\
\hline & ARm 2000 & ARm 2000 & СTM2.0 & & & & & & \\
\hline 25 & TND & TND & TND & & TND & & 77 & Older & 2012 \\
\hline 26 & TND & & 20 & & TND & & 28 & Recent & 2012 \\
\hline 27 & 51 & & & & 248 & & 34 & Recent & 2010 \\
\hline \multirow[t]{2}{*}{28} & 302 & & & & 403 & B & 95 & Older & 2010 \\
\hline & CAM1.5 & CAM1.5 & & & & & & & \\
\hline 29 & 182 & N/A & & & 605 & & 3 & Older & 2011 \\
\hline 30 & 224 & N/A & & & $19^{\prime} 510$ & CRF02_AG & 0 & Older & 2010 \\
\hline 31 & 255 & N/A & & & 1'642 & G & 21 & Older & 2010 \\
\hline 32 & 427 & N/A & & & $2^{\prime} 875$ & C & 0 & Older & 2010 \\
\hline
\end{tabular}

$\mathrm{TND}=$ target not detected; $\mathrm{N} / \mathrm{A}=$ not applicable; $\Delta$ days = days between collection of first and second sample. 

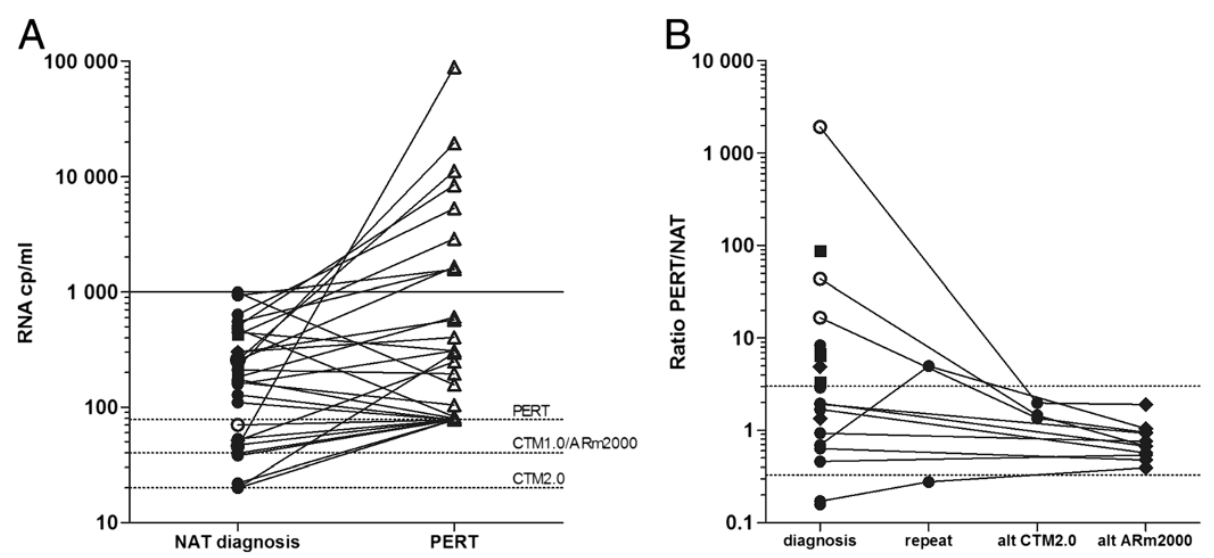

Figure 2 Comparison of NAT and PERT viral loads. A. Viral load measured by NAT and PERT at the time of diagnosis. PERT-derived viral loads were calculated based on the conversion shown in Figure 1. Samples below the limit of detection (LOD) were set to the LOD values as marked by the dotted lines. B. Ratio of PERT to NAT viral loads in the quantifiable range for PERT viral loads at the time of diagnosis and NAT viral loads measured at the time of diagnosis, during repeat testing and/or alternative (alt) testing with CTM2.0 or ARm2000. The area between dotted lines indicates changes in VL <3-fold. Symbols: o CTM1.0, • CTM2.0, ARm2000, • CAM1.5, $\Delta$ PERT.

seven patients (22\%) exhibiting a PERT VL $\geq 3$-fold higher than the NAT VL (patient ID 2, 4, 5, 22, 30-32 in Table 1, Figure 2B). A $\geq 3$-fold difference in VL is considered clinically significant according to NIH guidelines [12]. In four of these patients, the VL differed by as much as 10-1'000 fold (patient ID 2, 4, 5, 30), suggesting a severe VL underestimation by the respective NAT. For all but one (patient ID 22) of the seven patients, NAT VL had been determined either with CTM1.0 (patient ID 2, 4, 5) or CAM1.5 (patient ID 30-32), i.e. with tests for which VL underestimation has been reported previously [2,13-16]. Plasma for alternative NAT assessment was available for three patients assessed using CTM1.0, and testing with the successor CTM2.0 as well as with the ARm2000 platform both confirmed a VL >1'000 cp/ $\mathrm{ml}$, supporting the PERT assay results (Table 1 ). Consequently, the ratio of PERT to NAT VL decreased to $<3$-fold for these patients (Figure 2B).

Due to the lack of sample, we could not conduct repeat or alternative NAT-measurement for the four remaining patients with $\geq 3$-fold underestimation (patient ID 22, 30-32). However, comparison of NAT (CTM2.0 and $\mathrm{m} 2000$ ) and PERT VL in routine follow-up samples of two of these patients (patient ID 22 and 31) did not show a persistent difference in VL. Average fold difference of PERT to CTM2.0 and m2000 were $1.8( \pm 2.3)$ and $2.9( \pm 4.0)$ for patient ID $22(\mathrm{n}=7)$, and 5.5 and 3.0 for patient ID $31(n=2)$. This suggests technical variability or laboratory error as possible reasons for the apparent initial underestimation in these cases.

Alternative NAT measurements for all other patients (14 samples available) confirmed the low diagnostic NAT VL $\leq 1$ '000 cp/ml, indicating a genuine low VL at the time of diagnosis.

\section{Discussion}

In this study we investigated whether commercial viral load assays in use during the past few years provided reliable concentrations of HIV-1 RNA in plasma. We focused our analysis on patients with $\leq 1^{\prime} 000 \mathrm{cp} / \mathrm{ml}$, because the possible risks for untoward consequences of VL underestimation, namely a delay of ART or further virus transmission in a false belief of being non-infectious $[17,18]$, are highest in this group. Confirmatory testing of the VL was possible in only 32 of the 71 patients with an initial NAT $\mathrm{VL} \leq 1^{\prime} 000 \mathrm{cp} / \mathrm{ml}$ (45\%). Possible reasons for this low rate may include the following: Usually, a new blood sample was needed for a PERT assay at the SNCR, which required the patient returning to the physician who received the information that a PERT assay was considered necessary. If the initial physician had meanwhile transferred the patient to an HIV specialist, this information may not have been forwarded to the specialist. Moreover, the decision of whether a test is performed or not ultimately remains in the physician's responsibility; conceivable reasons for not performing a PERT assay include transient stay in the country or costs. Finally, it may not always have been possible to link a PERT result obtained for a patient sample received under full personal identity, with the coded personal information in the HIV notification.

Aside from these limitations, our analysis showed that the PERT assay confirmed the low diagnostic NAT VL in $78 \%$ of patients who had both tests. Seven patients had a clinically significant higher VL by PERT than NAT, with four patients showing a $>10$-fold difference. In three of these four patients we confirmed technical underestimation as the reason for the diagnostic low RNA VL, as demonstrated by significantly higher VL measurements when using alternative NAT platforms. 
These four most discrepant cases had all been tested with earlier NAT versions now outdated. Indeed, underestimation has been observed repeatedly for both CAM1.5 [13,15] and CTM1.0 $[2,14,16]$ in the past. One patient showed a $\geq 3$-fold NAT-VL underestimation on the CTM2.0 compared to PERT, which disappeared in later samples. In this case we cannot exclude some technical variance of the PERT assay.

The majority of patients were classified as having an older infection, thus minimizing concerns about large changes in VL between the first and second sample collected. Four patients classified as having a recent infection (patient ID 7, 16, 26, 27), and all had a NAT and PERT VL of $\leq 1^{\prime} 000 \mathrm{cp} / \mathrm{ml}$. As such low VL are rarely seen in patients with recent HIV-1 infection, we cannot exclude the possibility that the diagnostic NAT VL was falsely low, but nevertheless "confirmed" by PERT because the second sample was no longer in the acute, but in the chronic phase of infection in which the VL was already at the lower set-point. We can also not exclude the possibility that the classification as recent infection was false, because the diagnostic specificity of the algorithm used in these four cases was only 93\% [9]. Therefore, it is impossible to draw any safe conclusion regarding the true VL at the time of diagnosis in these four cases.

Both B and non-B subtypes were affected by NAT-based VL underestimation in our study, in agreement with others who found that underestimation was associated with a rare polymorphism in the viral genome [19]. With the introduction of CTM2.0, which uses dual target detection in gag and LTR, VL underestimation decreased dramatically $[16,20,21]$. The ARm2000 platform uses the IN region as target, and VL measurements performed by CTM2.0 and ARm2000 were found to correlate well [15]. Despite all technological improvement, VL underestimation may still occasionally occur even with the contemporary NAT generation [22]. This could also be the reason that one of the patients shown in Figure 1 has a PERT VL well outside the lower limit of the $95 \%$ confidence interval.

In our study population, severe NAT VL underestimation was restricted to patients for whom the initial diagnostic VL measurement was performed on NAT platforms outdated today. Although we did not find similar severe VL underestimation for any of the 23 patients assessed on either CTM2.0 or m2000, the upper limit of the $95 \%$ confidence interval of this zero frequency is at $12.2 \%$, suggesting a certain possibility for underestimation even with contemporary viral load tests. Continuation of the rule to confirm low VL with an alternative test is thus justified from a statistical viewpoint.

\section{Conclusion}

In light of the rapidly evolving global HIV-1 quasispecies it is virtually unavoidable that variants will arise which will be detected sub-optimally by a given sequencebased VL test. Confirmation of low VL by alternative methods like the sequence-independent PERT assay or a NAT targeting a different region of the viral genome will help to minimise such cases.

\section{Competing interests}

The authors declare that they have no competing interests.

\section{Authors' contributions}

BNV analysed the data, coordinated additional sample analysis and drafted the manuscript. CS supervised routine PERT assays. JBH carried out additional sample analyses on the Abbott RealTime HIV-1 m2000 system. JB participated in the design of the study and data evaluation. JS conceived the study and participated in its design and data evaluation. All authors read and approved the final manuscript.

\section{Acknowledgments}

The Swiss National Centre for Retroviruses received support for its work by contracts 10.001983 and 11.005726 with the Swiss Federal Office of Public Health. We would like to thank the SWISS HIV notification laboratories for providing information about NAT analysis platforms and HIV-1 subtypes. We also thank the technical staff at the SNCR for performing additional NAT analyses.

Received: 15 November 2013 Accepted: 10 February 2014 Published: 13 February 2014

\section{References}

1. Cobb BR, Vaks JE, Do T, Vilchez RA: Evolution in the sensitivity of quantitative HIV-1 viral load tests. J Clin Virol 2011, 52:S77-S82.

2. Gueudin M, Plantier JC, Lemee V, Schmitt MP, Chartier L, Bourlet T, Ruffault A, Damond F, Vray M, Simon F: Evaluation of the Roche Cobas TaqMan and Abbott RealTime extraction-quantification systems for HIV-1 subtypes. J Acquir Immune Defic Syndr 2007, 44:500-505.

3. Wirden M, Tubiana R, Marguet F, Leroy I, Simon A, Bonmarchand M, Ait-Arkoub Z, Murphy R, Marcelin AG, Katlama C, Calvez V: Impact of discrepancies between the Abbott realtime and cobas TaqMan assays for quantification of human immunodeficiency virus type 1 group $M$ non-B subtypes. J Clin Microbiol 2009, 47:1543-1545.

4. SFOPH: Das schweizerische HIV-Testkonzept - aktualisierte Übersicht über Technisches Konzept und Laborkonzept. Bulletin 51; 2006:1029.

5. Pyra $\mathrm{H}$, Boni J, Schupbach J: Ultrasensitive retrovirus detection by a reverse transcriptase assay based on product enhancement. Proc Natl Acad Sci U S A 1994, 91:1544-1548.

6. Boni J, Pyra H, Schupbach J: Sensitive detection and quantification of particle-associated reverse transcriptase in plasma of HIV-1-infected individuals by the product-enhanced reverse transcriptase (PERT) assay. J Med Virol 1996, 49:23-28.

7. Burgisser P, Vernazza P, Flepp M, Boni J, Tomasik Z, Hummel U, Pantaleo G, Schupbach J: Performance of five different assays for the quantification of viral load in persons infected with various subtypes of HIV-1. Swiss HIV Cohort Study. J Acquir Immune Defic Syndr 2000, 23:138-144.

8. Labbett W, Garcia-Diaz A, Fox Z, Clewley GS, Fernandez T, Johnson M Geretti AM: Comparative evaluation of the ExaVir Load version 3 reverse transcriptase assay for measurement of human immunodeficiency virus type 1 plasma load. J Clin Microbiol 2009, 47:3266-3270.

9. Schupbach J, Gebhardt MD, Scherrer AU, Bisset LR, Niederhauser C, Regenass S, Yerly S, Aubert V, Suter F, Pfister S, Martinetti G, Andreutti C, Klimkait T, Brandenberger M, Günthard HF; Swiss HIV Cohort Study: Simple estimation of incident HIV infection rates in notification cohorts based on window periods of algorithms for evaluation of line-immunoassay result patterns. PLoS One 2013, 8:e71662.

10. Schupbach J, Gebhardt MD, Tomasik Z, Niederhauser C, Yerly S, Burgisser $P$, Matter L, Gorgievski M, Dubs R, Schultze D, Steffen I, Andreutti C, Martinetti G, Güntert B, Staub R, Daneel S, Vernazza P: Assessment of recent HIV-1 infection by a line immunoassay for HIV-1/2 confirmation. PLoS Med 2007, 4:e343. 
11. SFOPH: HIV- und STI-Fallzahlen 2012: Berichterstattung, Analysen und Trends. Bundesamt für Gesundheit: Bulletin 21; 2013:376. 3003 Bern, Switzerland.

12. DoHHS: Guidelines for the use of antiretroviral agents in HIV-1-infected adults and adolescents. Panel on antiretroviral guidelines for adults and adolescents. 2013. http://aidsinfo.nih.gov/guidelines/html/1/adult-andadolescent-arv-guidelines; Section accessed 07/19/2013.

13. Glaubitz J, Sizmann D, Simon CO, Hoffmann KS, Drogan D, Hesse M, Lang G, Kroeh M, Simmler P, Dewald M, Haberhausen G, Lindauer A, Beyser K, Reber A, Baumeister A, Wolf E, Jaeger H, Babiel R: Accuracy to 2nd international HIV-1 RNA WHO Standard: assessment of three generations of quantitative HIV-1 RNA nucleic acid amplification tests. J Clin Virol 2011, 50:119-124.

14. Holguin A, Lopez M, Molinero M, Soriano V: Performance of three commercial viral load assays, Versant human immunodeficiency virus type 1 (HIV-1) RNA bDNA v3.0, Cobas AmpliPrep/Cobas TaqMan HIV-1, and NucliSens HIV-1 EasyQ v1.2, testing HIV-1 non-B subtypes and recombinant variants. J Clin Microbiol 2008, 46:2918-2923.

15. Karasi JC, Dziezuk F, Quennery L, Forster S, Reischl U, Colucci G, Schoener D, Seguin-Devaux C, Schmit JC: High correlation between the Roche COBAS (R) AmpliPrep/COBAS(R) TaqMan(R) HIV-1, v2.0 and the Abbott m2000 RealTime HIV-1 assays for quantification of viral load in HIV-1 B and non-B subtypes. J Clin Virol 2011, 52:181-186.

16. Taylor N, Schmid I, Egle A, Greil R, Patsch W, Oberkofler H: Initial evaluation of the Roche COBAS TaqMan HIV-1 v2.0 assay for determining viral load in HIV-infected individuals. Antivir Ther 2009, 14:1189-1193.

17. Gray RH, Wawer MJ, Brookmeyer R, Sewankambo NK, Serwadda D, WabwireMangen F, Lutalo T, Li X, van Cott T, Quinn TC, Team RP: Probability of HIV-1 transmission per coital act in monogamous, heterosexual, HIV-1-discordant couples in Rakai, Uganda. Lancet 2001, 357:1149-1153.

18. Pilcher CD, Tien HC, Eron JJ, Vernazza PL, Leu SY, Stewart PW, Goh LE, Cohen MS, Study Q, Consortium D-U-EAH: Brief but efficient: acute HIV infection and the sexual transmission of HIV. J Infect Dis 2004, 189:1785-1792

19. Korn K, Weissbrich B, Henke-Gendo C, Heim A, Jauer CM, Taylor N, Eberle J: Single-point mutations causing more than 100-fold underestimation of human immunodeficiency virus type 1 (HIV-1) load with the Cobas TaqMan HIV-1 real-time PCR assay. J Clin Microbiol 2009, 47:1238-1240.

20. Sizmann D, Glaubitz J, Simon CO, Goedel S, Buergisser P, Drogan D, Hesse M, Kroh M, Simmler P, Dewald M, Gilsdorf M, Fuerst M, Ineichen R, Kirn A, Pasche P, Wang Z, Weisshaar S, Young K, Haberhausen G, Babiel R: Improved HIV-1 RNA quantitation by COBAS AmpliPrep/COBAS TaqMan HIV-1 Test, v2.0 using a novel dual-target approach. J Clin Virol 2010, 49:41-46.

21. Pas S, Rossen JW, Schoener D, Thamke D, Pettersson A, Babiel R, Schutten M: Performance evaluation of the new Roche Cobas AmpliPrep/Cobas TaqMan HIV-1 test version 2.0 for quantification of human immunodeficiency virus type 1 RNA. J Clin Microbiol 2010, 48:1195-1200.

22. Sire JM, Vray M, Merzouk M, Plantier JC, Pavie J, Maylin S, Timsit J, LascouxCombe C, Molina JM, Simon F, Delaugerre C: Comparative RNA quantification of HIV-1 group M and non-M with the Roche Cobas AmpliPrep/Cobas TaqMan HIV-1 v2.0 and Abbott Real-Time HIV-1 PCR assays. J Acquir Immune Defic Syndr 2011, 56:239-243.

doi:10.1186/1471-2334-14-84

Cite this article as: Vetter et al:: Use of reverse-transcriptase-based HIV-1 viral load assessment to confirm low viral loads in newly diagnosed patients in Switzerland. BMC Infectious Diseases 2014 14:84.

\section{Submit your next manuscript to BioMed Central and take full advantage of:}

- Convenient online submission

- Thorough peer review

- No space constraints or color figure charges

- Immediate publication on acceptance

- Inclusion in PubMed, CAS, Scopus and Google Scholar

- Research which is freely available for redistribution

Submit your manuscript at www.biomedcentral.com/submit
Ciomed Central 